\title{
Pengaruh Jumlah Penduduk dan Upah Minimum Kota Terhadap Tingkat Pengangguran Terbuka di Pekanbaru tahun 2010-2017
}

\author{
Herman \\ Sekolah Tinggi Ilmu Ekonomi Riau
}

\begin{abstract}
The city of Pekanbaru has a population of 1,091,088 with a minimum wage of only Rp 2,557,486. This study aims to determine the effect of population and city minimum wages on the level of open unemployment in Pekanbaru in 20102017. This research is a quantitative research, with data obtained from secondary data, namely from BPS Kota Pekanbaru in 2010-2017. Data analysis with multiple regression. The results of the study show that: 1) The population has a negative and significant effect on the level of open unemployment in Pekanbaru City 2010-2017. 2) the city minimum wage does not significantly influence the unemployment rate in Pekanbaru City 2010-2017. 3) the magnitude of the influence of the total population and the city of Pekanbaru's minimum wage on the unemployment rate of 50.2 percent.
\end{abstract}

Keywords: total population, city minimum wage and open unemployment rate

\section{Pendahuluan}

Pekanbaru merupakan ibukota Provinsi Riau dimana untuk jumlah penduduk provinsi riau sendiri untuk tahun 2017 sebesar 6.657.911 jiwa sedangkan untuk kota Pekanbaru sendiri sebesar 1.091.088 jiwa. Dengan jumlah penduduk yang cukup besar maka akan berdampak pada tingkat pengangguran. Sebab pengangguran merupakan masalah makro ekonomi yang harus diselesaikan karena dapat mempengaruhi kelangsungan hidup masyarakat. Menurut Hartanto (2013) juga menambahkan bahwa tingginya jumlah penduduk di Indonesa dengan tingkat persebaran yang tidak merata menyebabkan banyaknya masalah kependudukan yang belum bisa teratasi hingga saat ini. Permasalahan kependudukan di Indonesia tersebut menurut diantaranya ketersediaan lahan perumahan yang semakin sempit, meningkatnya jumlah pengangguran, meningkatnya jumlah kaum urban diperkotaan, dan berdampak pada tingginya kaum tunawisma dan angka kriminal. Dimana luas wilayah kota pekanbaru adalah $632,26 \mathrm{Km}^{2}$. Dengan keadaan geologi 
relatief daerah datar, yaitu struktur tanah umumnya terdiri dari aluvual dan pasir dan pinggiran kota pada umumnya terdiri dari jenis tanah organosol dan humus yang merupakan rawa yang bersifat asam. Sehingga masyarakat akan sulit untuk membuka lahan terutama untuk pertanian sehingga akan menimbulkan adanya tingkat pengangguran dimana jumlah penduduk kota Pekanbaru tiap tahunnya selalu mengalami peningkatan. Salah satu tujuan dari pembangunan ekonomi adalah mengatasi pengangguran. Pengangguran dapat terjadi akibat ketidakseimbangan jumlah angkatan kerja dengan jumlah kesempatan kerja yang tersedia. Pekanbaru merupakan Kota berkembang yang mempunyai masalah pengangguran terbuka. Pengangguran terbuka adalah pengangguran dimana mereka sama sekali tidak memiliki pekerjaan. Berdasarkan sumber dari BPS Kota Pekanbaru 2018 bahwa tahun 2013 tingkat pengangguran terbuka sebesar 6,66 persen dan meningkat menjadi 9,20 persen pada tahun 2014 dan terakhir 2017 hanya turun yaitu 8,91 persen. Selain itu dimana jumlah penduduk Kota Pekanbaru selalu meningkat, hal tersebut dapat dilihat pada tabel berikut :

Tabel 1. Jumlah penduduk dan Upah Minimum Kota Pekanbaru

\begin{tabular}{|c|c|c|c|}
\hline Tahun & $\begin{array}{c}\text { Jumlah } \\
\text { Penduduk (jiwa) }\end{array}$ & $\begin{array}{c}\text { Laju } \\
\text { Pertumbuhan } \\
\text { Jumlah } \\
\text { Penduduk (\%) }\end{array}$ & $\begin{array}{c}\text { Upah Minimum } \\
\text { Kota (Rp) }\end{array}$ \\
\hline 2010 & 897.767 & - & 1.055 .000 \\
\hline 2011 & 929.247 & 3,51 & 1.135 .000 \\
\hline 2012 & 958.352 & 3,13 & 1.260 .000 \\
\hline 2013 & 984.674 & 2,75 & 1.450 .000 \\
\hline 2014 & 1.011 .467 & 2,72 & 1.775 .000 \\
\hline 2015 & 1.038 .118 & 2,63 & 1.925 .000 \\
\hline 2016 & 1.064 .566 & 2,55 & 2.146 .375 \\
\hline 2017 & 1.091 .088 & 2,49 & 2.557 .486 \\
\hline
\end{tabular}

Sumber : Kota Pekanbaru Dalam Angka, 2018

Berdasarkan tabel 1 diatas dapat digambarkan bahwa jumlah penduduk kota pekanbaru setiap tahunnya selalu mengalami peningkatan, yaitu dari tahun 2013 sebesar 984.674 jiwa dan terus meningkat menjadi 1.091 .088 jiwa pada tahun 2017 atau laju pertumbuhannya selama 5 tahun sebesar 10,81\%. Menurut Sukirno (2013), Penduduk yang bertambah dari waktu ke waktu dapat menjadi pendorong maupun 
penghambat kepada perkembangan ekonomi. Penduduk yang semakin bertambah akan menyebabkan kenaikan jumlah angkatan kerja. Namun apabila kenaikan jumlah angkatan kerja ini tidak diimbangi dengan kenaikan jumlah kesempatan kerja maka hal ini akan menimbulkan pengangguran.

Sebab pertambahan penduduk ini perlu menjadi perhatian khusus bagi pemerintah Kota Pekanbaru mengingat tingkat pengangguran terbuka di Kota Pekanbaru dari tahun 2013 sebesar 6,66\% dan meningkat menjadi 9,20\% pada tahun 2014 dan pada tahun 2017 turun sedikit menjadi 8,91\%. Dimana upah yang ada di kota Pekanbaru pada tahun 2017 sebesar Rp 2.557.486 dan tahun 2016 sebesar Rp 2.146.375 dengan kenaikan selama setahun sebesar Rp 411.111.(BPS Pekanbaru dalam angka 2018). maka bagi suatu perusahaan besarnya tingkat upah akan menyebabkan banyaknya biaya yang dikeluarkan sehingga perusahaan pada akhirnya akan mengurangi jumlah tenaga kerja yang digunakan sehingga akan menambah jumlah penganguran yang ada.

Selain itu diketahui bahwa inflasi di Kota Pekanbaru mengalami peningkatan. Pada tahun 2013 terjadi kenaikan inflasi yang sangat drastis. Penyebab tingginya inflasi pada tahun 2013 adalah kenaikan harga BBM. Selain itu tarif listrik juga turut mempengaruhi tingkat inflasi di Kota Pekanbaru.

Berdasarkan penjelasan dan permasalahan yang ada tersebut peneliti tertarik untuk membuat penelitian berjudul" Pengaruh Jumlah Penduduk dan Upah Minimum Kota terhadap Jumlah Pengangguran di Kota Pekanbaru Kota tahun 2010-2017”

\section{Tinjauan Pustaka}

\section{Pengangguran}

Pengangguran dalam arti luas adalah penduduk yang tidak berkerja tetapi sedang mencari perkerjaan atau sedang mempersiapkan suatu usaha baru atau penduduk yang tidak mencari pekerjaan karena sudah diterima bekerja tetapti mulai bekerja. Pengangguran adalah masalah makroekonomi yang mempengaruhi manusia secara langsung dan merupakan yang paling berat. Kebanyakan orang kehilangaan pekerjaan berarti penurunan standar kehidupan dan rekanan psikologis. Jadi tidaklah mengejutkan jika pengangguran menjadi topik yang sering dibicarakan 
dalam perdebatan politik dan para politis sering mengklaim bahwa kebijakan yang mereka tawarkan akan membantu menciptakan lapangan kerja (Mankiw, 2006). Selain itu pengangguran diartikan sebagai suatu keadaan dimana seseorang yang tergolong dalam angkatan kerja ingin mendapatkan pekerjaan belum dapat memperolehnya (Sukirno, 2000). Menurut Badan Pusat Statistik (BPS) dalam indikator ketenagakerjaan, pengangguran adalah penduduk yang tidak bekerja namun sedang mencari pekerjaan atau sedang mempersiapkan suatu usaha baru atau penduduk yang tidak mencari pekerjaan karena sudah diterima bekerja tetapi belum mulai bekerja. Jadi tidak mengejutkan apabila pengangguran menjadi topik yang sering diperbincangkan dalam perdebatan poltik oleh para politisi yang seringkali mengkaji bahwa kebijakan yang mereka tawarkan akan membantu terciptanya lapangan pekerjaan (Mankiw,2000). Untuk mengukur tingkat pengangguran suatu wilayah bisa diperoleh melalui dua pendekatan :

a. Pendekatan Angkatan Kerja (Labour force approach), Besar kecilnya tingkat pengangguran dapat dihitung berdasarkan presentase dan perbandingan jumlah antara orang yang menganggur dan jumlah angkatan kerja.

$$
\text { Penganguran }=\frac{\text { Jumlah yang menganggur }}{\text { Jumlah Angkatan Kerja }} \times 100 \%
$$

b. Pendekatan pemanfaatan tenaga kerja (Labour utilization approach),

1. Bekerja penuh (employed) adalah orang-orang yang bekerja penuh atau jam kerjanya mencapai 35 jam per minggu.

2. Setengah menganggur adalah mereka yang bekerja namun belum dimanfaatkan penuh atau jam kerjanya dalam seminggu kurang dari 35 jam.

Pengangguran Terbuka, Pengangguran ini tercipta sebagai akibat pertambahan lowongan pekerjaan yang lebih rendah dari pertambahan tenaga kerja. Sebagai akibatnya dalam perekonomian semakin banyak jumlah tenaga kerja yang tidak dapat memperoleh pekerjaan. Efek dari keadaan ini di dalam suatu jangka masa yang cukup panjang mereka tidak melakukan suatu pekerjaan. Jadi mereka menganggur secara nyata dan separuh waktu, dan oleh karenanya dinamakan pengangguran terbuka. Pengangguran terbuka dapat pula wujud sebagai akibat dari 
kegiatan ekonomi yang menurun, dari kemajuan teknologi yang mengurangi penggunaan tenaga kerja, atau sebagai akibat dari kemunduran perkembangan suatu industri

\section{Penduduk}

Penduduk adalah orang dalam matranya sebagai pribadi, anggota keluarga, anggota masyarakat, warga negara dan himpunan kuantitas yang bertempat tinggal di suatu tempat dalam batas wilayah tertentu (Mantra, 2009). Pertumbuhan penduduk adalah merupakan keseimbangan yang dinamis antara kekuatan-kekuatan yang menambah dan mengurangi jumlah penduduk. Pertumbuhan penduduk diakibatkan oleh beberapa komponen yaitu: kelahiran (fertilitas), kematian (mortalitas), migrasi masuk dan migrasi keluar. Selisih antara kelahiran dan kematian disebut pertumbuhan alamiah (natural increase), sedangkan selisih antara migrasi masuk dan migrasi keluar disebut migrasi netto. Penduduk merupakan semua orang yang berdomosili di wilayah geografis Republik Indonesia selama 6 bulan atau lebih dan mereka yang berdomisili kurang dari 6 bulan dengan tujuan untuk menetap (BPS, 2014).

Menurut aliran Malthusian: terjadi ketidak seimbangan antara pertumbuhan penduduk dengan pertumbuhan makanan, dalam hal ini pertumbuhan penduduk berjalan berdasarkan deret ukur, sedangkan pertumbuhan/pertambahan makanan berdasarkan deret hitung. Oleh karena itu, pertumbuhan penduduk harus dibatasi. Pembatasan jumlah penduduk dapat dilaksanakan dengan dua cara, yaitu preventive dan positive check.

Badan Pusat Statistik (2011) mendifinisikan penduduk adalah semua orang yang berdomisili di wilayah geografis Republik Indonesia selama enam bulan atau lebih dan atau mereka yang berdomisili kurang dari enam bulan tetapi bertujuan menetap. Pertumbuhan penduduk merupakan keseimbangan yang dinamis antara kekuatankekuatan yang menambah dan kekuatan yang mengurangi jumlah penduduk. Pertumbuhan penduduk diakibatkan oleh empat komponen yaitu : kelahiran (fertilitas), kematian (mortalitas), migrasi masuk, dan migrasi keluar (Subri,2003). 
Pertumbuhan penduduk adalah suatu perubahan populasi yang terjadi sewaktuwaktu dan bisa dihitung sebagai perubahan dalam jumlah individu atau dalam sebuah populasi menggunakan satuan "per waktu unit" untuk pengukuran.

Pertumbuhan penduduk dapat disebut juga sebagai dinamika penduduk. Nah, Dibyo Soegimo (2009) dalam bukunya menjelaskan ada 3 klasifikasi pertumbuhan penduduk yang harus kita pahami, yakni sebagai berikut :

a. Pertumbuhan penduduk termasuk cepat apabila pertumbuhan $2 \%$ lebih dari jumlah penduduk tiap tahun,

b. Pertumbuhan penduduk termasuk sedang apabila pertumbuhan itu antara $1 \%$ $2 \%$,

c. Pertumbuhan penduduk termasuk lambat apabila pertumbuhan itu antara $1 \%$ atau kurang.

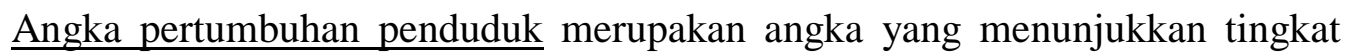
pertambahan penduduk per tahun dalam jangka waktu tertentu yang dinyatakan dengan persen (\%). Nah, angka sekian persen di atas akan kita dapatkan setelah menghitung angka pertumbuhan penduduk :

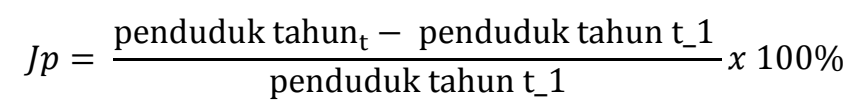

Ket :

Jp $\quad=$ Jumlah Penduduk

Tahun_t $=$ Jumlah Penduduk tahun sekarang

Tahun_t-1= Jumlah Penduduk tahun sebelumnya.

\section{Upah Minimum Kota}

Upah merupakan uang dan sebagainya yang dibayarkan sebagai pembalas jasa atau sebagai pembayar tenaga yang sudah dikeluarkan untuk mengerjakan sesuatu, gaji, imbalan, hasil akibat (dari suatu perbuatan), resiko (Kamus Besar Bahasa Indonesia,2002).

Upah adalah hak pekerja/buruh yang diterima dan dinyatakan dalam bentuk uang sebagai imbalan dari pengusaha atau pemberi kerja kepada pekerja/buruh yang ditetapkan dan dibayarkan menurut suatu perjanjian kerja, kesepakatan, atau peraturan perundang-undangan, termasuk tunjangan bagi pekerja/buruh dan 
keluarganya atas suatu pekerjaan dan/atau jasa yang telah atau akan dilakukan (Pasal 1 angka 30 Undang-Undang Nomor 13 Tahun 2003 tentang Ketenagakerjaan).

Menurut pasal 1 angka 1 Peraturan Menteri Tenaga Kerja No.PER-01/MEN/1999 tentang Upah Minimum, upah minimum adalah Upah Bulanan Terendah yang terdiri dari upah pokok dan tunjangan tetap.

Menurut pasal 1 angka 2 Keputusan Menteri Tenaga Kerja dan Transmigrasi No.KEP-226/MEN/2000 tentang perubahan pasal 1, pasal 3, pasal 4, pasal 8, pasal 11, pasal 20, pasal 21 Peraturan Menteri Tenaga Kerja PER-01/MEN/1999 tentang upah minimum, upah minimum

propinsi adalah upah yang berlaku untuk seluruh kabupaten atau kota di satu propinsi. Besarnya upah minimum untuk setiap wilayah propinsi atau kabupaten atau kota tidak sama karena tergantung nilai kebutuhan hidup minimum (KHM) di daerah bersangkutan.

Menurut Sonny Sumarsono (2003), Upah adalah suatu penerimaan sebagai imbalan dari pengusaha kepada karyawan untuk suatu pekerjaan atau jasa yang telah atau akan dilakukan dan dinyatakan atau dinilai dalam bentuk uang yang ditetapkan atas dasar suatu persetujuan atau peraturan perundang-undangan serta dibayarkan atas dasar suatu perjanjian kerja antara pengusaha dengan karyawan termasuk tunjangan, baik untuk karyawan itu sendiri maupun untuk keluarganya.

T.Gilarso,2003, Upah dalam arti sempit khusus dipakai untuk tenaga kerja yang bekerja pada orang lain dalam hubungan kerja (sebagai karyawan/buruh).

Hasibuan (1997), upah adalah balas jasa yang dibayarkan kepada para pekerja harian dengan berpedoman atas perjanjian yang disepakati membayarnya.

Pada awalnya, Permenaker No. 01/MEN/1999 menyebut bahwa istilah Upah Minimum untuk kabupaten/kota adalah Upah Minimum Regional Tingkat II (UMR Tk.2). Namun setelah adanya Kepmenakertrans No. 226/MEN/2000, istilah itu berganti nama menjadi Upah Minimum Kota (UMK). Upah Minimum Kota adalah upah minimum yang berlaku di daerah kabupaten/kota. 
Jumlah Penduduk adalah semua orang yang berdomisili di wilayah geografis Republik Indonesia selama enam bulan atau lebih dan atau mereka yang berdomisili kurang dari enam bulan tetapi bertujuan menetap (Jiwa) 2010-2017

Upah Minimum Kota adalah dibayarkan sebagai pembalas jasa atau sebagai pembayar tenaga yang sudah dikeluarkan untuk mengerjakan sesuatu (Rp) 20102017

Tingkat Pengangguran: adalah jumlah tenaga kerja yang kehilangan pekerjaan dan sedang mencari kerja)terhadap jumlah total tenaga kerja (Jiwa) 2010-2017.

\section{Kerangka Konseptual}

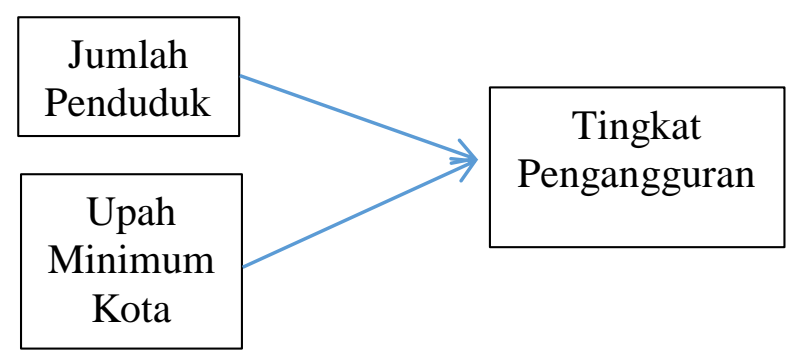

\section{Variabel Penelitian}

a. Jumlah Penduduk(jiwa) sebagai variabel bebas (X1)

b. Upah Minumum Kota (Rp) sebagai variabel bebas (X2)

c. Tingkat Pengangguran (\%) sebagai variabel terikat (Y)

\section{Metode Penelitian}

Jenis penelitian ini adalah penelitian kuantitatif, jenis data yang digunakan dalam penelitian ini adalah dataa sekunder yang diperoleh dari BPS Kota Pekanbaru dengan periode waktu tahun 2010 hingga 2017. Metode analisis data yang digunakan adalah analisis regresi berganda, dan bentuk persamaan regresi yaitu : $\mathrm{TP}=\beta_{0}+\mathrm{b} \beta 1 \mathrm{JP} 1+\beta 2 \mathrm{UMK} 2+\mathrm{e}$.

$\mathrm{TP}=$ tingkat pengangguran, $\mathrm{JP}=\mathrm{jumlah}$ penduduk, UMK: Upah minimum Kota. 


\section{Hasil Dan Pembahasan}

Tabel 2. Descriptive Statistics

\begin{tabular}{|c|c|c|c|}
\hline & Mean & $\begin{array}{c}\text { Std. } \\
\text { Deviation }\end{array}$ & $\mathrm{N}$ \\
\hline $\begin{array}{c}\text { Tingkat } \\
\text { Pengangguran }\end{array}$ & 8.6475 & 1.51037 & 8 \\
\hline $\begin{array}{c}\text { Jumlah } \\
\text { Penduduk }\end{array}$ & 9.96909 & 66976.4250 & 8 \\
\hline $\begin{array}{c}\text { Upah Minimum } \\
\text { Kota }\end{array}$ & 1.662 .983 & 5.30656 & 8 \\
\hline
\end{tabular}

Berdasarkan tabel 2 diatas dapat digambarkan bahwa rata-rata tingkat pengangguran kota pekanbaru adalah 8.65\%, dan Jumlah Penduduk 9.96909 jiwa, sedangkan tingkat Upah Minimum Kota hanya Rp1.662983. maka hal tersebut dapat dijelaskan bahwa rata-rata Upah Minimum Kota Pekabaru hanya Rp1.662983.

Tabel 3. Regresi Linier Berganda

\begin{tabular}{|c|c|c|c|}
\hline \multirow{2}{*}{\multicolumn{2}{|c|}{ Model }} & \multicolumn{2}{|c|}{$\begin{array}{l}\text { Unstandardized } \\
\text { Coefficients }\end{array}$} \\
\hline & & B & Std. Error \\
\hline \multirow[t]{3}{*}{1} & (Constant) & 71.644 & 23.280 \\
\hline & $\begin{array}{l}\text { Jumlah } \\
\text { Penduduk }\end{array}$ & $-7.726 \mathrm{E}-5$ & .000 \\
\hline & $\begin{array}{l}\text { Upah Minimum } \\
\text { Kota }\end{array}$ & $8.432 \mathrm{E}-6$ & .000 \\
\hline
\end{tabular}

Berdasarkan tabel 3 diatas diperoleh persamaan regresi linier berganda:

Tingkat Pengangguran :71.644, -7.726 Jumlah Penduduk +8.432 Upah Minimum Kota. Maka hal tersebut dapat dujelaskan yaitu Nilai 71.644 yaitu jika nilai variabel jumlah penduduk dan upah minimum kota Pekanbaru bernilai nol, maka tingkat pengangguran terbuka di kota Pekanbaru sebesar 71.644. Nilai -7.726 yaitu jika jumlah penduduk naik satu-satuan, maka tingkat penganguran angkan mengalami penurunan sebesar 7.726 satuan. Nilai 8.432 yaitu jika upah minimum kota meningkat satu-satuan, maka tiangkat pengangguran akan meningkat sebesar 8.432 satuan. 
Tabel 4. Hasil Uji_t

\begin{tabular}{|c|c|c|c|c|c|}
\hline & & \multicolumn{2}{|c|}{$\begin{array}{l}\text { Unstandardized } \\
\text { Coefficients }\end{array}$} & \multirow[b]{2}{*}{$\mathrm{t}$} & \multirow[b]{2}{*}{ Sig. } \\
\hline \multicolumn{2}{|c|}{ Model } & B & Std. Error & & \\
\hline \multirow[t]{3}{*}{1} & (Constant) & 71.644 & 23.280 & 3.077 & .028 \\
\hline & \begin{tabular}{|l|} 
Jumlah \\
Penduduk
\end{tabular} & $-7.726 \mathrm{E}-5$ & .000 & -2.631 & .046 \\
\hline & \begin{tabular}{|l|} 
Upah \\
Minimum \\
Kota
\end{tabular} & $8.432 \mathrm{E}-6$ & .000 & 2.275 & .072 \\
\hline
\end{tabular}

a. Dependent Variable: Tingkat Pengangguran

Berdasarkan tabel 4 diatas dapat dijelaskan bahwa nilai Sig. Variabel jumlah penduduk adalah 0.046 maka dapat disimpulkan bahwa variabel jumlah penduduk memiliki nilai < dari 0.05 sehingga dapat disimpulkan bahwa jumlah penduduk berpengaruh signifikan terhadap tingkat pengangguran. Dan nilai Sig. Variabel upah minimum kota 0.072 maka dapat disimpulkan bahwa variabel upah minimum kota memiliki nilai > dari 0.05 sehingga dapat disimpulkan bahwa upah minimum kota tidak berpengaruh signifikan terhadap tingkat pengangguran kota Pekanbaru.

Tabel 5. Hasil Uji_F

\begin{tabular}{|l|l|r|r|r|r|}
\hline \multicolumn{2}{|l|}{ Model } & df & Mean Square & F & Sig. \\
\hline \multirow{2}{*}{1} & Regression & 2 & 5.147 & 4.535 & $.075^{\mathrm{a}}$ \\
\cline { 2 - 6 } & Residual & 5 & 1.135 & & \\
\cline { 2 - 6 } & Total & 7 & & & \\
\hline
\end{tabular}

Berdasarkan tabel 5 diatas, dapat dijelaskan bahwa nilai Sig. $0.075>$ dari 0.05 maka dapat disimpulkan bahwa seluruh variabel bebas tidak berpengaruh signifikan terhadap variabel terikat.

Tabel 6. Hasil Koefesien Determinasi

\begin{tabular}{l|c|c|l|l|}
\hline Model & $\mathrm{R}$ & $\begin{array}{c}\mathrm{R} \\
\text { Square }\end{array}$ & $\begin{array}{c}\text { Adjusted } \\
\mathrm{R} \text { Square }\end{array}$ & $\begin{array}{l}\text { Std. Error of } \\
\text { the Estimate }\end{array}$ \\
\hline 1 & $.803^{\mathrm{a}}$ & .645 & .502 & 1.06533 \\
\hline Predictors: (Constant), Upah Minimum Kota, Jumlah Penduduk \\
Dependent Variable: Tingkat Pengangguran
\end{tabular}

Berdasarkan tabel 6 diatas, diperoleh bahwa kemampuan variabel terikat dijelaskan oleh variabel bebas sebesar 0.502. maka hal ini model yang digunakan sudah sesuai. 


\section{Pengaruh jumlah penduduk terhadap tingkat pengangguran}

Berdasarkan hasil penelitian diperoleh bahwa Jumlah penduduk berpengaruh negatif dan signifikan terhadap tingkat pengangguran terbuka, hal ini didukung penelitian yang dilakukan oleh Dita Dewi Kuntiarti, 2018, pengaruh inflasi, jumlah penduduk dan kenaikan upah minimum terhadap pengangguran terbuka di provinsi banten tahun 2010-2015. Selain itu juga didukung oleh peneliti Suwarni, 2016 pengaruh jumlah penduduk dan inflasi terhadap pengangguran di kota makassar 2002-2014, yang menyatakan bahwa jumlah penduduk berpengaruh berpengaruh signifikan dan berhubungan negatif terhadap pengangguran. Karena penambahan jumlah penduduk disini adalah penduduk yang sudah bekerja tetapi tidak penuh jam kerja atau belum memiliki pekerjaan yang tetap.

\section{Pengaruh Upah Minimum Kota terhadap tingkat pengangguran}

Berdasarkan hasil penelitian diperoleh bahwa upah minimum kota tidak berpengaruh signifikan terhadap tingkat pengangguran. Hal ini sesuai dengan penelitian yang dilakukan oleh Fitri Khoirulana, 2017, bahwa upah minimum kota tidak berpengaruh terhadap tingkat pengangguran. Karena peningkatan upah minimum kota tidak begitu besar, sehingga masyarakat akan mencari peluang usaha sendiri.

\section{Kesimpulan}

Adapun kesimpulan dalam penelitian ini adalah :

a. Jumlah penduduk berpengaruh negatif yang signifikan terhadap tingkat pengangguran terbuka di kota Pekanbaru (2010-2017).

b. Upah minimum kota tidak berpengaruh signifikan terhadap tingkat pengangguran terbuka di kota Pekanbaru (2010-2017)

c. Besarnya pengaruh Jumlah penduduk dan upah minimu kota terhadap tingkat pengangguran terbuka di kota Pekanbaru (2010-2017) sebesar 50,2\%.

Adapun saran dalam penelitian ini adalah :

a. Bagi pemerintah kota Pekanbaru untuk membuka lagi lapangan usaha, artinya jumlah penduduk yang semakin besar akan berpeluang mengurangi pengangguran jika diimbangi dengan lapangan usaha yang lebih besar lagi. 
b. Dan bagi pemerintah kota untuk menigkatkan upah minimum kota yang tinggi, artinya dari tahun sebelumnya harus memiliki perbedaan yang signifikan.yaitu dapat dilihat bahwa dari tahun 2010 sampai 2015 hanya berkisar 1.000.000,

\section{DAFTAR PUSTAKA}

Dita Dewi Kuntiarti, 2018, pengaruh inflasi, jumlah penduduk dan kenaikan upah minimum terhadap pengangguran terbuka di provinsi banten tahun 20102015, Jurnal Pendidikan dan Ekonomi, volume 7, Nomor 1, tahun 2018.

Fitri Khoirulana 2017 analisis pengaruh jumlah penduduk, produk domestik regional bruto (pdrb), upah minimum kab/kota (umk), dan inflasi terhadap tingkat pengangguran terbuka di provinsi jawa tengah periode tahun 20112015.

Hasibuan 1997. Manajemen Sumber Daya Manusia. (jilid-9). Jakarta : PT. Toko Gunung Agung.

Kamus Besar Bahasa Indonesia,2002.

Keputusan Menteri Tenaga Kerja dan Transmigrasi No: PER-01/MEN/1999 jo.

Keputusan Menteri Tenaga Kerja dan Transmigrasi Nomor KEP. 226/MEN/2000.

Keputusan Menteri Tenaga Kerja dan Transmigrasi Nomor 226 Tahun 2000

Tentang Perubahan Pasal 1, Pasal 3, Pasal 4, Pasal 8, Pasal 11, Pasal 20 dan

Pasal 21 Permenakertrans Nomor Per-01/MEN/1999 tentang Upah Minimum.

Mankiw, 2000. Teori Makro Ekonomi, Edisi Ke Empat, Erlangga, Jakarta.

Mantra,2009.Demografi Umum. Yogyakarta: Pustaka Pelajar Offset.

Nah, Dibyo Soegimo. 2009. Geografi untuk SMA/MA Kelas XI Jakarta, Perbukuan Departemen Pendidikan Nasional.

Pasal 1 angka 1 Peraturan Menteri Tenaga Kerja No.PER-01/MEN/1999 tentang Upah Minimum.

Pasal 1 angka 2 Keputusan Menteri Tenaga Kerja dan Transmigrasi No.KEP226/MEN/2000 tentang perubahan pasal 1, pasal 3, pasal 4, pasal 8, pasal 
11, pasal 20, pasal 21 Peraturan Menteri Tenaga Kerja PER-01/MEN/1999 tentang upah minimum, upah minimum.

Pasal 1 angka 30 Undang-Undang Nomor 13 Tahun 2003 tentang Ketenagakerjaan.

Sonny Sumarsono 2003. Ekonomi Manajemen Sumber Daya Manusia danKetenagakerjaan. Yogyakarta : Graha Ilmu.

Subri, 2003. Ekonomi Sumber Daya Manusia dalam Perspektif Pembangunan. PT RajaGrafindo Persada. Jakarta.

Sukirno, 2000, Sadono. 2000. Makroekonomi Modern. Jakarta: PT Raja Drafindo Persada.

Sukirno, Sadono. 2013. Makroekonomi : Teori Pengantar. Jakarta : PT. Raja Grafindo Persada.

Suwarni 2016, Pengaruh Jumlah Penduduk Dan Inflasi Terhadap Pengangguran Di Kota Makassar 2002-2014.

T.Gilarso,2003,Pengantar Ilmu Ekonomi Makro. Edisi Pertama. IKAPI. Yogyakarta.

BPS. Kota Pekanbaru Dalam Angka, 2018. 